DOI 10.15407/mics2020.11.037

УДК 930+902

Вікторыя Тарасевіч,

аспірант кафедры археалогіі і спецыяльных гістарычных дысцыплін,

магістр гістарычных навук

Беларускі дзяржаўны ўніверсітэт

tarasevichvika475@gmail.com

https://orcid.org/0000-0003-2106-1382

\title{
ГІСТОРЫЯ ВЫВУЧЭННЯ ЖАНОЧАГА СТРОЮ КУЛЬТУРЫ СМАЛЕНСКА-ПОЛАЦКІХ ДОЎГІХ КУРГАНОЎ: ВЫНIКI I СУЧАСНЫ СТАН
}

\section{ІСТОРІЯ ВИВЧЕННЯ ЖІНОЧОГО ЮВЕЛІРНОГО ВБРАННЯ КУЛЬТУРИ СМОЛЕНСЬКО-ПОЛОЦЬКИХ ДОВГИХ КУРГАНІВ : ПІДСУМКИ ТА НИНІШНІЙ СТАН}

Статтю присвячено історії вивчення, а також аналізу ступеня вивченості жіночого металевого вбрання (костюма) культури смоленсько-полоцьких довгих курганів, яку прийнято ототожнювати 3 літописними кривичами. Авторка проаналізувала низку наукових публікацій, на основі яких було зроблено висновок про те, що цілеспрямоване вивчення цього питання почалось з 1960-х рр. У вивченні жіночого ювелірного убору кривичів можна виокремити три періоди. Перший період (1960-ті - початок 1990-х рр.) характеризується поступовим відходом від сприйняття жіночого убору «культури довгих курганів» тільки як джерела: убір став предметом дослідження. Другий період (1990-ті - 2017 рр.) характеризується цілеспрямованим вивченням жіночого убору в рамках поняття культури смоленсько-полоцьких довгих курганів (КСПДК). У цей час виникають досить детальні типології окремих елементів жіночого убору КСПДК. 32017 р. починається третій період (2017 рік - наш час). Він виділений на основі виявлених 
1 Енуков, В. В. (1990). Ранние этапь формирования смоленско-полоцких кривичей (по археологическим данным)

Москва: Знак Почета, 4; Шмидт, Е. А. (2012). Кривичи Смоленского Поднепровья и Подвинья (в свете археологических данных). Смоленск, 62.

2 Нефёдов, В. С. (200๑). О времени возникновения культуры смоленско-

полоцких длинных курганов. В Археология и история Пскова и Псковской земли: материалы науч. семинара 1996-1999 (с. 197). Псков; Шмидт, Е. А. Кривичи Смоленского Поднепровья и Подвинья, 60-61.

3 Нефёдов, В. С. О времени возникновения, 197; Енуков, В. В. (2018). Культура смоленских длинных курганов и древности днепро-донской лесостепи. В Археология Древней Руси: проблемы и открытия. Материалы международной конференции, посвященной 100-летию со дня рождения Д. А. Авдусина. Труды исторического факультета МГУ (Вып. 140, сер. II: Исторические исследования, с. 7577). Москва: Издательство Московского университета.

4 Плавинский, Н. А. (2012). К вопросу о финале культуры смоленско-полоцких длинных курганов в Брасловском Поозерье (по материалам раскопок курганного могильника 0пса в 2010 г.). в Славяне Восточной Европы накануне образования Древнерусского государства. Материалы международной конференции, посвященной 110-летию со дня рождения Ивана Ивановича Ляпушкина (1902-1968) 3-5 декабря 2012 г. (с. 227-228).

безкурганних поховань КСПДК, у яких трапляються нові «нетипові» жіночі прикраси. Це спонукало дослідників до переосмислення традицій поховального обряду та характерних елементів жіночого убору кривичів. Серед основних дослідників можна назвати імена Є. А. Шмідта, В. В. Сєдова, В. В. Снукова, В. С. Нєфьодова. За результатами багаторічних досліджень було виділено речі, які виступають як «культурні маркери», запропоновано типології та хронологію окремих елементів жіночого металевого вбрання: скроневих кілець, головних вінець, тримачів. Встановлено, що при дослідженні жіночого ювелірного вбрання культури смоленсько-полоцьких довгих курганів переважає «мікрорегіональний підхід»: типології інвентарю переважно базуються на матеріалах смоленської частини ареалу культури. Отже, існує «розрив» у рівні вивченості жіночого металевого вбрання між російськими та білоруськими дослідниками: на території Білорусі вивчення його локальних особливостей та хронології тільки почалось.

Ключові слова: культура смоленсько-полоцьких довгих курганів, кривичі, Білоруське Подвиння, жіноче ювелірне вбрання, історіографія, В. В. Сєдов, С. А. Шмідт, В. В. Снуков, В. С. Нєфьодов.

\section{Уступ}

У канцы I - пачатку II тыс. н.э. на тэрыторыі Беларускага Падзвіння і Смаленскага Падняпроўя пражывала насельніцтва культуры смаленска-полацкіх доўгіх курганоў. На дадзены момант гэтая культура дастаткова ўпэўнена атаясамліваецца 3 летапіснымі крывічамі ${ }^{1}$. Даследаванні некалькіх апошніх дзясяткаў гадоў дазваляюць акрэсліць час і месца фарміравання культуры - яна сфарміравалася ў Смаленскім Падняпроўі i, верагодна, у паўночна-усходніх рэгіёнах Беларусі не пазней за сярэдзіну VIII ст. ${ }^{2}$ Паступова ў навуцы ўсталёўваецца меркаванне, што культура сфарміраванался на падставе балцкага і славянскага этнічнага кампанента
Славянскі кампанент, на думку даследчыкаў, пранік ў асяроддзе КСПДК (на тэрыторыю Смаленскага Падняпроўя) 3 поўдня, 3 тэрыторыі Сярэдняга Падняпроўя, і звязваецца 3 насельніцтвам, якое пакінула пасля сябе валынцаўскі культурна-храналагічны гарызонт ${ }^{3}$. Фінал культуры прыходзіцца на канец X-першую палову-сярэдзіну ХІ стст. (прадстаўлены помнікамі ў паўночна-заходняй частцы Беларускага Падзвіння) ${ }^{4}$.

3 пачатку XX ст. даследчыкі звярнулі асаблівую ўвагу на пахавальныя насыпы вельмі вялікага памеру. Тэрмін «доўгія курганы» быў уведзены ў навуковы ўжытак А. А. Спіцыным, і з гэтага часу трывала замацаваўся за пэўным колам старажытнасцяў, якія і былі аб'яднаны па фармальнай прык- 
5 Спицын, А. А. (1899). Расселение древнерусских племен по археологическим данным. Журнал Министерства народного просвещения, 311-312; Спицын, А. А. (1903). Удлиненные и длинные курганы. В Записки отделения русской и славянской археологии Русского археологического общества (V (1), с. 196-202). Санкт-Петербург: Тип. И. Н. Скороходова.

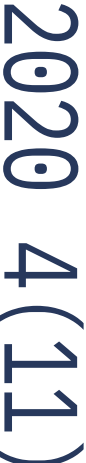

6 Михайлова, Е. Р. (2014). Вещевой комплекс культуры псковских длинных курганов: типология и хронология. Saarbrücken: LAPLAMBERT Academic Publishing, 3 .

7 Плавінскі, М. А. (2011). Полацкасмаленскіх доўгіх курганоў культура. у Археалогія Беларусі: эниыклапедыя (Т. 2, с. 202-203). Мінск.

8 Шмидт, Е. А. (1968). О смоленских длинных курганах. В Славяне и Русь (с. 225-226). Москва: Наука. меце ў агульнае паняцце ${ }^{5}$. Пэўны час пад паняцем «доўгія курганы» ці «культура доўгіх курганоў» меліся на ўвазе старажытнасці, якія зараз адносяцца да культуры пскоўскіх доўгіх курганоў (далей - КПДК), арэал якой ахоплівае ўсё ўзбярэжжа Пскоўска-Чудскага возера, басейны рэк Вялікай, Плюсы, Лугі, верхняга цячэння Заходняй Дзвіны і сярэдняга цячэння Ловаці, верхняй Полы, Верхняй Волгі, басейны Мсты і Верхняй Малогі 6 , і культуры смаленска-полацкіх доўгіх курганоў (далей - КСПДК), межы распаўсюджання помнікаў якой на поўначы дасягаюць рэк Вялікая і Ловаць, на ўсходзе даходзяць да вярхоўяў Вопі (правы прыток Дняпра), на поўдні пралягаюць ад вярхоўяў Сажа праз басейн Беразіны Дняпроўскай да вярхоўяў Віліі, на захадзе ідуць ад возера Нарач да возера Дрысвяты (мал. 1) ${ }^{7}$.

Існаванне тэрміналагічнай праблемы звязана 3 пэўнымі перыядамі ў асэнсаванні курганных старажытнасцяў «тыпу доўгіх курганоў», а таксама 3 аб'ёмам назапашаных археалагічных крыніц, якія існавалі на момант працы таго ці іншага даследчыка У канцы 1960-х гадоў Я. А. Шмідт звярнуў увагу на тое, што нягледзячы на аднолькавы пахавальны абрад (крэмацыя) і традыцыю насыпання кургана, «доўгія курганы» неаднародныя. «По-видимому, было бы целесообразно заменить общий термин «длинные курганы» территориально-хронологическими

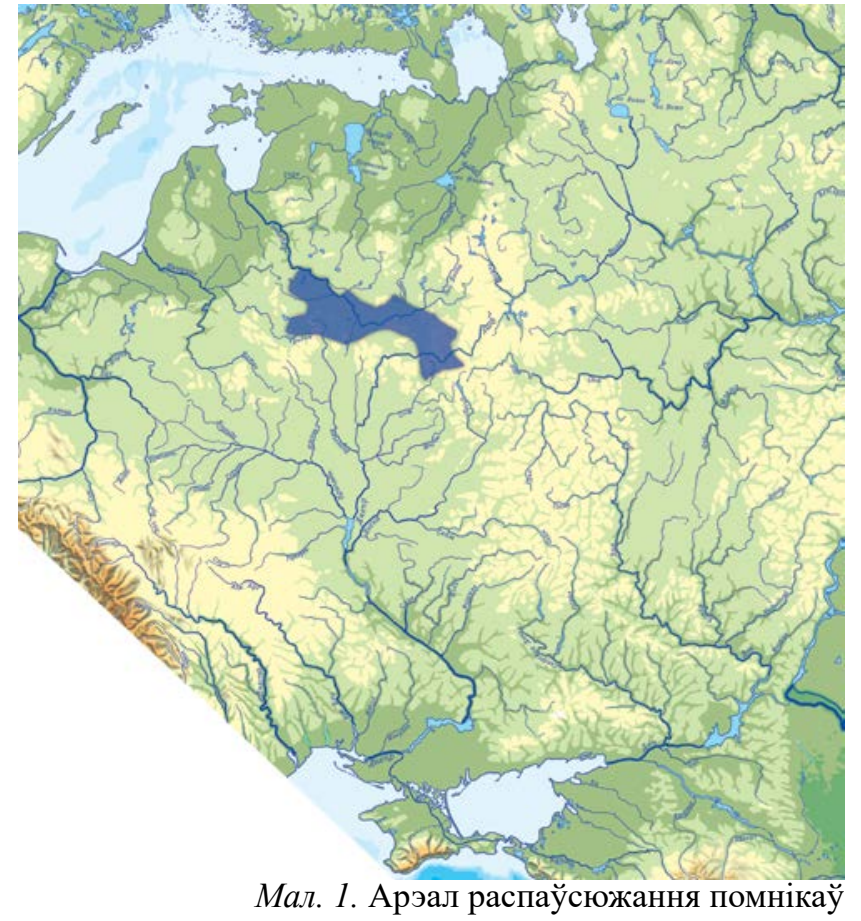

наименованиями отдельных культур» ${ }^{8}$. Аднак, толькі з 1990-х гадоў назіраецца паступовая замена паняцця «культура доўгіх курганоў» тэрмінамі КПДК і КСПДК.

Культура атрымала назву «доўгіх курганоў» на падставе адной адметнасці ў пахавальнай традыцыі. Для КСПДК характэрны абрад трупаспалення, які ў большасці выпадкаў здзяйсняўся па-за межамі будучага пахавання. Пасля спалення цалкам ці часткова састылыя парэшткі (кальцынаваныя косткі) збраліся і пераносіліся ў месца пахавання, над якімі насыпаўся курган, як ра- 
9 Енуков, В. В. Ранние этапы формирования, 31-49.

10 у межах гэтага артыкула панняцці «строй» $i$ «ўбор» выкарыстоўваюцца як сінанімічныя. Паняцце строй звычайна ўключае ў сябе не толькі металічны убор, але i асобныя элементы адзення. Аднак, у выпадку з КСПДК крыніцы, якія дазвалялі 6 аднавіць адзенне, адсутнічаюць, што звязана з асаблівасцямі пахавальнай абраднасці культуры.

11 Шмидт, Е. А. (1970). К вопросу об этнической принадлежности женского инвентаря из смоленских длинных курганов. В Материалы по исследованию Смоленской области (Вып. VII, с. 222). Москва: Московский рабочий; Енуков, В. В. Ранние этапы формирования, 5266.

12 Зариня, А. (1960). Латгальские женские головные венки вайнаги -

VI-XIII вB. B Arheologia un etnografia. Rakstu krejums (T. 2, c. 79-95). Riga; Зариня, А. (1970). Одежда древних латалов. VII-XIII вв. Рига: Зинатне;

Волкайте-Куликаускене, Р. (1997).

Одежда и украшения балтов (I-XVI вв.). Vilnius, Lietuvos Istorijos instituto.

13 Шмидт, Е. А. К вопросу об этнической принадлежности женского инвентаря, 219-235; Шмидт, Е. А. Кривичи Смоленского Поднепровья и Подвинья; Седов В. В. (1974). Длинные курганы кривичей. Москва: Наука; Енуков, В. В. Ранние этапы формирования; Нефёдов, В. С. (2009). Височные кольца культуры смоленско-полоцких длинных курганов (по ней лічылася, «доўгі». Як зараз відавочна, могільнікі КСПДК не складаюцца толькі 3 «доўгіх» насыпаў, курганы могуць быць падоўжанымі, набліжанымі да чатырохкутных, паўсферычнымі. Незалежна ад формы, насып мог утрымліваць як адно пахаванне так і некалькі 9

Сярод пахавальнага інвентару, акрамя так называемай ляпной ад рукі керамікі «з плечуком», прыкметна вылучаецца жаночы металічны уббор ${ }^{10}$. Пахавальны інвентар у большасці выпадкаў моцна дэфармаваны ў пахавальным вогнішчы, што значна ўскладняе вызначэнне тыпу, колькасці рэчаў, i ix месца ў сістэме крывіцкага жаночага убоpy ${ }^{11}$.

Магчыма, па прычныне «непаўнаты крыніц», на дадзены момант няма абагульняючых навуковых прац, прысвечаных тэме рэканструкцыі жаночага строю КСПДК. Крыніцай для рэканструкцый даследчыкі абіраюць пахаванні па абрадзе інгумацыі, якія, у большасці, маюць неабходную «паўнату» для аднаўлення сістэмы жаночых упрыгажэнняў. У якасці прыклада такіх прац можна назваць манаграфіi, прысвечаныя рэканструкцыі адзення балцкіх плямёнаў ${ }^{12}$.
Інвентар пахаванняў па абрадзе крэмацыі дазваляе «рэканструяваць» не строй у цэлым, але яго «сістэму» ў трох «складніках»: упрыгажэнні галавы, шыі і грудзяў, рук. Так, асобныя элементы крывіцкага жаночага строю вывучаліся такімі даследчыкамі, як Я. А. Шмідт, В. В. Сядоў, У. В. Енукоў, Ю. М. Лесман, В. С. Няфёдаў ${ }^{13}$. Неабходна адзначыць дзейнасць А. Р. Міхайлавай, якая сабрала і прааналізавала «рэчавы комплекс» КПДК, вылучыўшы агульныя і лакальныя яго варыянты ${ }^{14}$. Падобныя працы, прысвечаныя «рэчаваму комплексу» КСПДК, адсутнічаюць

\section{Этапы вывучэння жаночага строю КСпдК: агульная характарыстыка}

У гісторыі вывучэння жаночага строю КСПДК варта вылучыць некалькі перыядаў. Пачатковы перыяд (1960-я - пачатак 1990-х гг.) харатарызуецца паступовым адыходам ад успрыняцця жаночага строю КСПДК толькі як крыніцы ў даследаваннях, прадметам якіх былі летапісныя крывічы, якіх ба-

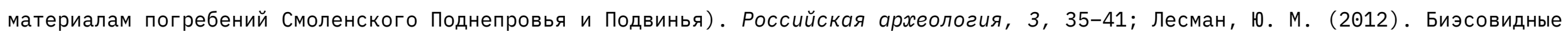

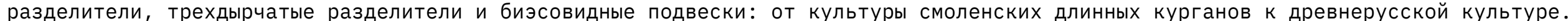
В Славяне Восточной Европы накануне образования Древнерусского государства. Материалы международной конференции, посвященной 110-летию со дня рождения Ивана Ивановича Ляпушкина (1902-1968) 3-5 декабря 2012 2. (с. 228-232). Санкт-Петербург. 
15 Шмидт, Е. А. О смоленских длинных курганах, 225.

16 Енуков, В. В. Ранние этапы формирования.

17 Шмидт, Е. А. Кривичи Смоленского Поднепровья и Подвинья; Штыхаў, Г. В. (1992). Крывічы: Па матэрыялах раскопак курганоў у Паўночнай Беларусі. Мінск: Навука і тэхніка. чылі ў археалагічнай культуры «доўгіх курганоў». Паступова жаночы строй КСПДК стаў выступаць як прадмет даследавання. Пошукі адказу на пытанне пра этнічную прыналежнасць «культуры доўгіх курганоў» у пэўнай ступені ўплывалі на асэнсаванне даследчыкамі рэчавага комплексу. Пачатак вывучэння «строю» КСПДК можна звязаць 3 дзейнасцю Я. А. Шмідта і В. В. Сядова, якая, у пэўнай ступені, праходзіла ва ўмовах палемікі між імі як прыхільнікамі «славянскай» i «балцкай» канцэпцый энтічнай прыналежнасці культуры «доўгіх курганоў (i тут відавочны ўплыў уяўлення пра аднароднасць помнікаў «тыпу доўгіх курганоў», нягледзячы на абгрунтаваны доказ памылковасці гэтага ўяўлення дадзены Я. А. Шмідтам) ${ }^{15}$. В. В. Сядоў і Я.А. Шмідт адстойвалі супрацьлеглыя меркаванні. Вывучэнне жаночага ўбору КСПДК, як найбольш кансерватыўнага элемента матэрыяльнай культуры, якое вялося ў кантэксце агульнай тэндэнцыі да пошуку адказу на пытанне пра этнічную прыналежнасць, паўплывала на накірункі даследаванняў. Так, працы насычаны звесткамі пра магчымыя прататыпы асобных элементаў строю і аналогіi. Аднак, назіраецца паварот ад абагульнення і пошуку аналогій да вывучэння асаблівасцяў канкрэтных рэчаў, ix формы, функцыянальнай прыналежнасці.
У вывучэнні жаночага строю КСПДК можна вылучыць і другі перыяд (1990-я 2017 гг). Гэта, у першую чаргу звязана $з$ пераасэнсаваннем паняцця «культура доўгіх курганоў» у бок выкладзенай Я. А. Шмідтам ў 1968 г. канцэпцыі пра неаднароднасць помнікаў «тыпу доўгіх курганоў». У пэўнай ступені на гэта паўплывала манаграфія У. В. Енукова «Ранние этапы формирования смоленско-полоцких кривичей» (1990), якая да гэтага часу з'яўляецца адзінай найбольш поўнай прцай, у якой на даволі добрым метадычным узроўні харатарызуецца жаночы ўбор КСПДК ${ }^{16}$. У гэты час былі канчаткова сфарміраваныя тыпалогіi асобных элементаў жаночага строю, i, што даволі істотна, была спроба вылучыць храналагічныя індыкатары для КСПДК, у якасці якіх акурат і выступалі некаторыя элементы жаночага строю. Важнымі для гэтага перыяду з'яўляюцца таксама манаграфіі Г. В. Штыхава і Я. А. Шмідта ${ }^{17}$. Можна адзначыць шэраг істотных дасягненняў у вывучэнні жаночага строю КСПДК ў гэты перыяд: як прыклад, гэта пэўныя зрухі ў вывучэнні праблемнага пытання пра час пачатку i завяршэння фарміравання ўстойлівага набору жаночых упрыгажэнняў (В. С. Няфёдаў), удакладнены гіпотэзы наконт часу і месца фарміравання КСПДК (Я. А. Шмідт, В. С. Няфёдаў), а таксама распачалася праца па пошуку прататыпаў для 
18 Нефёдов, В. С. О времени возникновения культуры, 191-199; Шмидт, Е.А. Кривичи Смоленского Поднепровья и Подвинья; Нефёдов, В. С. Височные кольца, 35-41.

19 Михайлова, Е. Р. Вещевой комплекс.

20 Матэрыялы даследаванняў рыхтуюцца да друку .

21 Шмидт, Е. А. К вопросу об этнической принадлежности женского инвентаря, 219-235. асобных элементаў жаночага строю КСПДК (В.С. Няфёдаў) ${ }^{18}$.

У гэты ж час выходзіць манаграфія А. Р. Міхайлавай «Вещевой комплекс культуры псковских длинных курганов: типология и хронология» (2014), у якой найбольш поўна прадстаўлена матэрыяльная культура КПДК ${ }^{19}$. Гэтая праца паказвае тое, што КПДК і КСПДК маюць даволі значныя адрозненні ў тым ліку і ў матэрыяльнай культуры, што сведчыць аб немагчымасці іх аб'яднання ў нейкае агульнае «культурнае» утварэнне.

Трэці этап (2017 - наш час) у даследаваннях жаночага строю КСПДК і пахавальнай абраднасці культуры ў цэлым мажліва распачаць з 2017 года, калі на тэрыторыі некропаля Наўры II (Мядзельскі Мінская вобласць) экспедыцыяй пад кіраўніцтвам А. М. Плавінскага быў выяўлены бескурганны могільнік крывічоў. У ім на раскапанай плошчы ў слаі пахаванай глебы фіксаваліся аб'екты, якія 3 пэўнай ступенню ўпэўненасці можна аднесці да пахаванняў. Сярод інвентару, які сустракаўся на даследаванай плошчы, як у аб'ектах, так і па-за імі, фіксаваліся асобныя «класічныя» элементы жаночага строю КСПДК, такія як спіральныя пранізкі, абойміцы ад галаўнога венчыка, 14-і гранныя пацеркі 3 празрыстага блакітнага шкла i інш., так зусім новыя для культуры элементы жано- чага строю, аналогій якім пакуль не выяўлена ${ }^{20}$. Даследаванні некропаля Наўры II працягнуліся ў 2018-2020 гг. (М. А. Плавінскі, В. М. Тарасевіч). Дадзены помнік прымушае вывучаць жаночы строй КСПДК на падставе бескурганных пахаванняў культуры.

\section{Даследчыкі і вынікі ix працы}

Бадай, першай працай, прысвечанай жаночаму ўбору КСПДК можна лічыць артыкул Я.А. Шмідта «К вопросу об этнической принадлежности женского инвентаря из смоленских длинных курганов» ${ }^{21}$. Матэрыялы ўласных раскопак помнікаў, якія адносяцца да КСПДК у басейне Дняпра (каля вёсак Цуркоўка, Катынь, Васілеўшчына, Калодня, Арэфіна), у басейне Сожа (каля вёсак Слабада-Глушыца, Елаўцы), і ў басейне Заходняй Дзвіны (Заазер'е, Забор'е, Акатава, Дрокава) дазволілі Я. А. Шмідту зрабіць пэўныя абагульненні інвентару жаночых пахаванняў. Ён быў скампанаваны ім наступным чынам: упрыгажэнні галавы (спіральныя пранізкі, абойміцы ад галаўнога венчыка, ланцужкі, скроневыя колцы, званочкападобныя i бі-S-падобныя трымальнікі, трапецападобныя падвескі), упрыгажэнні шыі і грудзей (пацеркі і шыйныя грыўні), упрыгажэнні рук 
22 Там жа, 223-231.

23 Там жа, 230.

24 Там жа, 226-227.

25 Там жа, 225.

26 Там жа, 233-234. (пярсцёнкі і бранзалеты) ${ }^{22}$. Асобна выдзелена катэгорыя побытавых рэчаў. Прыведзены спіс рэчаў, якія даследчык не аднёс ні да якой катэгорыі: «...бронзовые круглые орнаментированные бляшки, костяные птички, бронзовые колокольчики, пуговицеобразные подвески и некоторые другие предметы» ${ }^{23}$.

Я. А. Шмідт прыводзіць тыпалогію галаўных венчыкаў і вылучае два іх тыпы (стужкавыя і жгутавыя), а таксама тыпалогію скроневых колцаў, дзе таксама вылучае два тыпы (плоскія скроневыя колцы 3 сіметрычна заходзячымі канцамі (тып 1) і колцы з плоскай серпападобнай ніжняй часткай, якая мае шэраг адтулін, праз якія прасоўвалі тонкія драцяныя колцы 3 трапецападобнымі падвескамі (тып 2)). Дасдедчык звярнуў увагу на тыпалагічнае падабенства скроневага колца другога тыпу 3 плоскімі шыйнымі грыўнямі, якія бытавалі ў Прыбалтыцы, а таксама 3 грыўнямі, якія сустракаюцца ў разанскіх могільніках ${ }^{24}$. Я. А. Шмідт вылучыў два тыпы трымальнікаў (у тэрміналогіі Я. А. Шмідта - «подвески»): дротавыя (бі-S-падобныя) i «сферические колпачковидные» (званочкападобныя). На думку Я. А. Шмідта, такія трымальнікі з'яўляліся састаўным элементам галаўнога венчыка ${ }^{25}$.

Найбольш блізкімі аналогіямі хараткэрнага для КСПДК інвентару Я. А. Шмідт лічыў інвентар з усходніх рэгіёнаў Прыбал- тыкі. Таксама даследчык звяртаў увагу на адрозненні пахавальнага жаночага інвентару 3 «смаленскіх доўгіх курганоў» ад інвентару «пскоўскіх доўгіх курганоў». На падставе аналогій аўтар сцвярджаў пра немагчымасць фарміравання жаночых упрыгажэнняў на падставе папярэдніх культур. «Все имеющиеся материалы V-VII веков н. э. пока говорят за то, что система украшений из женских погребений длинных курганов не могла возникнуть из предшествующих культур Смоленского Поднепровья, так как среди этих материалов нет вещей, которые можно было бы поставить как исходные формы в типологическом развитии рассмотренных нами украшений. Это же самое можно сказать и о пространствах, прилегающих к Смоленскому Поднепровью с востока и юго-востока» ${ }^{26}$.

У якасці аргумента на карысць гіпотэзы пра фарміраванне КСПДК на тэрыторыі Літвы прыводзілася тое, што ў пахаваннях на гэтай тэрыторыі і на паселішчах V-VI стст. сустракаюцца скроневыя колцы 3 заходзячым канцамі, канцы якіх маюць ромбападобнае сячэнне. Іх Я.А. Шмідт лічыў прамым прататыпам для выдзеленых ім жа колцаў першага тыпу, і датаваў час іх з'яўлення сярэдзінай I тыс. н. э. Як аргумент таксама прыводзілася распаўсюджанне галаўных венчыкаў на тэрыторыі Сярэдняй і Усходняй Літвы і на значнай тэрыторыі Латвіi ${ }^{27}$. 

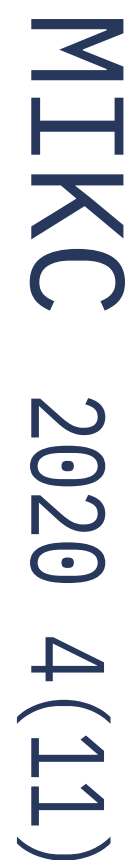

28 Шмидт, Е. А. (2006). Особенности этнокультурного развития племен Смоленского Поднепровья и смежных территорий в VIII - X вв. Н. э. Гістарычна-археалагічны зборнік, 22, 114.

29 Шмидт, Е. А. (2008). К вопросу об этнической принадлежности кривичей. В Романовские чтения - 4: сборник трудов Международной научной конферениии, 22-23 ноября 2007 года, г. Могилев (с. 35-44). Могилев; Шмидт, Е. А. Кривичи Смоленского Поднепровья и Подвинья, 41-55; Шмидт, Е. А. (2013). Шугайлово (комплекс археологических памятников). Смоленск: Свиток.

30 Шмидт, Е. А. (2012). Кривичи Смоленского Поднепровья и Подвинья, 41-55.

31 Там жа, 41-55.

32 Там жа, 44-55.

$3 з$ Там жа, 49.
У працах наступных гадоў даследчык па сутнасці прынцыпова не змяняў выкладзеных палажэнняў, але ўдакладніў ix. 3 назапашваннем новых крыніц стала магчымым вылучыць рэчы, якія сустракаюцца па ўсім арэале культуры, і сведчаць пра яе адзінства (спіралькі, абойміцы ад галаўнога венчыка вайнагі, прывескі розных тыпаў, ланцужкі і інш.) ${ }^{28}$. Шэраг прац, прысвечаных вынікам шматгадовых палявых даследаванняў Я. А. Шмідта, маюць главы, у якіх прыводзяцца агульныя звесткі пра жаночы пахавальнь ўбор КСПДК ${ }^{29}$.

Абагульненні даследчыка пра сістэму жаночых упрыгажэнняў КСПДК маюцца ў манаграфіi «Кривичи Смоленского Поднепровья и Подвинья (в свете археологических данных), у якой ён вылучае дзве групы упрыгажэнняў: упрыгажэнні галавы 1 ўпрыгажэнні шыі, грудзей і рук ${ }^{30}$.

Да ўпрыгажэнняў галавы Я. А. Шмідт аднёс «...проволочные спирали, разъединительные пластины-обоймицы, биэсовидные, колпачковидные и трехдырчатые подвескидержатели, трапециевидные, ромбовидные и других форм привески, цепочки, височные кольца нескольких типов и некоторые

Мал. 2. Тыпалогіі трымальнікаў культуры смаленска-полацкіх доўгіх курганоў, прапанаваныя У. В. Енуковым, Я. А. Шмідтам другие предметы» ${ }^{31}$. Ён вылучыў тры тыпы трымальнікаў КСПДК: бі-S-падобныя, трохдзюркавыя і званочкападобныя («колпачковидные») (мал. 2). Быў дапоўнены асартымент падвесак: акрамя трапецападобных узгадваюцца ромбападобныя і грыбападобныя падвескі ${ }^{32}$. Тыпалогія галаўных венчыкаў, прапанаваная даследчыкам ў 1970-я г., не ўдакладнялася. Аднак, была дапоўнена тыпалогія скроневых колцаў: да двух вылучаных тыпаў скроневых колцаў быў даданы трэці тып: «круглопроволочные браслетообразные разомкнутые височные кольца с завитком на одном конце» (мал. 3$)^{33}$

Да ўпрыгажэнняў шыі, грудзяў і рук былі аднесены «...стеклянные бусы, составлявшие ожерелья, либо такие же ожерелья, но, кроме стеклянных бус, включавшие бронзовые спирали малого диаметра и подвески...бронзовые шейные гривны. ...

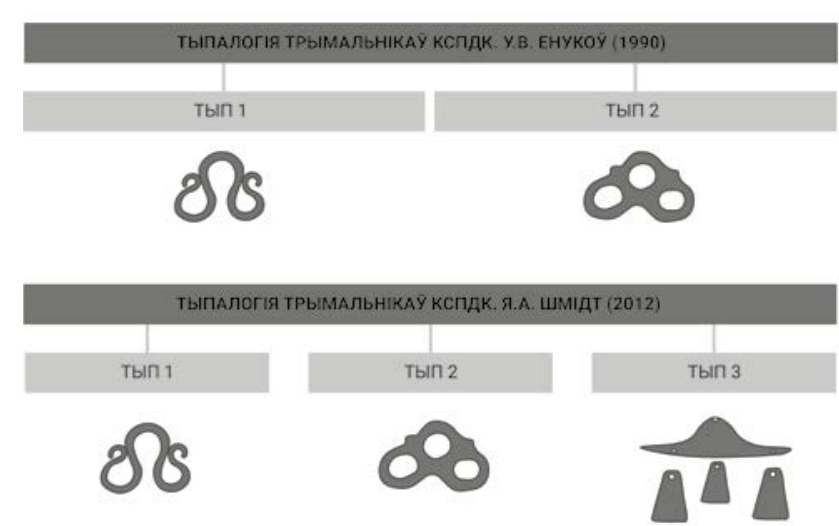


Мал. 3. Тыпалогіi скроневых колцаў культуры смаленска-полацкіх доўгіх курганоў, прапанаваныя У. В. Енуковым,

Я. А. Шмідтам, В. С. Няфёдавым

34 Там жа, 50 .

35 Там жа, 54

36 Шмидт, Е. А. Особенности этнокультурного развития племен, 118; Шмидт, E. A. К вопросу об этнической принадлежности кривичей, 100-102; Шмидт,

E. А. Кривичи Смоленского Поднепровья и Подвинья, 60-63.

37 Седов, В. В. Длинные курганы кривичей; Седов, В. В. (1982). Восточные славяне в VI-XIII вв. В Археология СССР с древнейших времён до средневековья (Т. 14, с. 50-51). Москва: Наука; Седов, В. В. (1993). Височные кольца культуры смоленско-полоцких длинных курганов. В Час, помнікі,

людзі. Памяиі рэпрэсаваных археолагаў. Тэзісы дакладаў міжнароднай канферэнuыi ў Мінску 27-30 кастрычніка 1993

г. (с. 116-118). Мінск; Седов, В. В.

(1994). Очерки по археологии славян. Москва, 89-98; Седов, В. В. (1995).

Славяне в раннем средневековье.

Москва: НПБО «Фонд археологии», 235237; Седов, В.В. (1999). Древнерус-

ская народность. Москва: Языки русской культуры, 140-145.

38 Седов, В. В. Длинные курганы кривичей, 32; Седов, В. В. Восточные славяне, 51-52.

39 Седов, В. В. Височные кольца,

116-118; Седов, В. В. Очерки по ар-

хеологии славян, 89-98; Седов, В. В

Славяне в раннем средневековье, 235;

Седов, В. В. Древнерусская народность, 143-144.

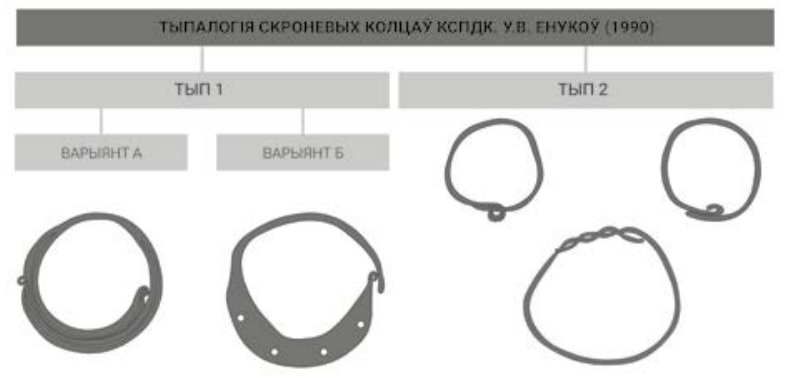

характэрнымі толькі для Смаленскай часткі арэала культуры ${ }^{35}$.

Я. А. Шмідт застаўся прыхільнікам «балцкай» канцэпцыі энтічнай прыналежнасці КСПДК ${ }^{36}$.

У пэўнай ступені тэарэтычным асэнсаваннем асобных элементаў жаночага ўбору «культуры доўгіх курганоў» займаўся В. В. Сядоў. У яго маецца шэраг прац манаграфічнага характару, у якіх закрананецца жаночы металічны ўбор КСПДК ${ }^{37}$. Агульная характарыстыка інвентару КСПДК мянялася 3 трансфармацыяй поглядаў даследчыка на паняцце «доўгія курганы». Так, у працах да сярэдзіны 1990-х гг. ён лічыў серыю прадметаў жаночага ўбору, якія зараз складаюць матэрыяльную культуру КСПДК, лакальнай асаблівасцю «смаленскай часткі арэала культуры доўгіх курганоў», на падставе якіх нельга рабіць высновы пра этнічную прыналежнасць насельніцтва ${ }^{38}$.

Асобная ўвага даследчыка была наодежда на груди скреплялась металлическими подковообразными фибулами и часто на одежде крепили подвески, служившие украшениями и, возможно, оберегами» ${ }^{34}$.

Да ліку рэчаў, характэрных для КСПДК, Я. А. Шмідт аднёс і падвескі-качачкі, а таксама круглыя арнаментаваныя бляхі з умбонападобным выступам ў цэнтры, якія лічыў дадзена серпападобным скроневым колцам КСПДК (тып 2 па Я. А. Шмідту). У шэрагу прац В.В. Сядоў аспрэчывае раней прапанаванае меркаванне Я. А. Шмідта пра паходжанне такога тыпу скроневых колцаў ад плоскіх (пласцінкавых) шыйных грыўняў, якія сустракаюцца ў літоўскіх старажытнасцях ${ }^{39}$. Варта адзначыць, што даследчык сам 
40 Седов, В. В. Длинные курганы кривичей, 32 .

41 Седов, В. В. Очерки по археологии славян, 92-93.

42 Там жа, 93-95.

43 Там жа, 94-95; Седов, В. В. Древнерусская народность, 143-145.

44 Седов, В. В. Славяне в раннем средневековье, 229.

45 Там жа, 8.

46 Там жа, 53-54. пэўны час прытрымліваўся гэтага ж меркавання ${ }^{40}$.

В. В. Сядоў даволі абгрунтавана прывёў доказы на карысць таго, што такія скроневыя колцы не могуць паходзіць ад шыйных грыўняў: час бытавання «летто-литовских шейных гривн» - X-XI стст., а найбольш ранніх канец VIII ст. (серпападобныя скроневыя колцы бытавалі з пачатку існавання культуры (сярэдзіна - другая палова VIII ст.)); несупадзенне фармальных прыкмет скроневых колцаў тыпу 1, варыянт а (тыпалогія У.В. Енукова) $з$ пласцінкавымі літоўскімі шыйнымі грыўнямі (адсутнасць завіткоў на канцах ў грыўнях, адсутнасць дротавай асновы, розныя арнаментальныя матывы) ${ }^{41}$.

Ён прапанаваў ўласную гіпотэзу пра паходжанне скроневых колцаў. На думку В. В. Сядова, на фарміраванне скроневых колцаў такога тыпу аказалі ўплыў 1) бранзалетападобныя скроневыя колцы, якія былі ў карыстанні ў пяпярэдняй КСПДК тушамлінска-банцараўскай культуры; 2) скроневыя колцы «луннічнага тыпу», якія былі шырока распаўсюджаны «в далеких Дунайских землях» ${ }^{42}$. На думку аўтара, серпападобнае пашырэнне ў скроневых колцаў КСПДК гэта падражанне менавіта «дунайскім» луннічным колцам ${ }^{43}$. Даследчык да апошняга адстойваў гіпотэзу «дунайскіх міграцый» ў асяроддзе КСПДК.
Недзе з сярэдзіны 1990-х гадоў В. В. Сядоў пачынае выкарыстоўваць тэрмін «культура смаленска-полацкіх доўгіх курганоў», кажучы ўжо не пра нейкія лакальныя асаблівасці інвентару ў межах агульнага паняцця «культура доўгіх курганоў», а пра асобную культуру. «Но самым существенным различием является наличие в захоронениях рассматриваемых памятников своеобразного инвентаря, включающего предметы женского головного убора типа летто-литовских вайнаг, полусферические бляхи, проволочные биэсовидные украшения, трапециевидные и грибовидные привески, костяные привески в виде птичек» ${ }^{44}$.

У. В. Енуковым была пастаўлена мэта праз аналіз пахавальных старажытнасцяў тэрыторыі Смаленскага Падняпроўя і Віцебскага Падзвіння апошняй чвэрці I тыс. н.э. рэканструяваць этнакультурныя працэсы, у выніку якіх сфарміраваліся «смаленска-полацкія крывічы» ${ }^{45}$. У манаграфіі дэталёва разгледжаны матэрыяльная культура КСПДК ў тым ліку і жаночы пахавальны інвентар, вылучаны тыповыя рэчы.

Даследчык не ставіў мэты распрацоўкі пэўных тыпалогій інвентару КСПДК, улічваючы ступень захаванасці крыніц, аднак ён скарэктаваў тыпалогію скроневых колцаў, прапанаваную Я. А. Шмідтам (мал. 3) ${ }^{46}$. Таксама ім былі вылучаны два тыпы «лан- 
47 Там жа, 59.

48 Там жа, 75.

49 Гавритухин, И. О. (1997). Маленькие трапециевидные подвески с каймой из прессованных точек по нижнему краю. Гістарычна-археалагічны зборнік, 12, 43-58.

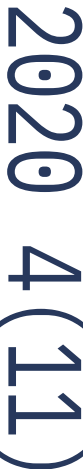

50 Там жа, 46-50.

51 Нефёдов, В. С. О времени возникновения культуры, 191-199; Нефёдов, В. С. (2002). Салтовские древности в смоленских длинных курганах. Гістарычна-археалагічны зборнік, 17, 131-139; Нефёдов, В. С. (2003). Некоторые замечания об украшениях культуры смоленских длинных курганов из раскопок в Старой Ладоге. В Ладога - первая столииа Руси. 1250 лет непрерывной жизни. Седьмые чтения памяти Анны Мачинской (с. 58-67). Санкт-Петербург: Нестор-История, ИИ РАН; Нефёдов, В. С. Височные кольца, 35-41; Нефёдов, В. С. (2011). Смоленские кривичи и Русь: североевропейские и древнерусские

изделия в смоленских длинных курганах. В Труды III (XIX) Всероссийского археологическою съезда (Т. II, с. 75-77). Москва; Нефёдов, В. С. (2012). Ранние этапы политогенеза на территории Смоленской земли (конец IX- первая половина XI в.). В Северная Русь и проблемы формирования Древнерусского государства. Сборник материалов Международной научной конференции (Вологда - Кириллов - Белозерск, 6-8 июня 2012 г.) (с. 89-113). Вологда: Древности Севера. цугатрымальнікаў» (у тэрміналогіі У. В. Енукова) - бі-S-падобныя і трохдзюркавыя, i прапанавана гіпотэза наконт трансфармацыі першага тыпу ў другі (мал. 2) ${ }^{47}$. Даследчык звярнуў ўвагу на пэўныя рэчы, не характэрныя для іншых культурных утварэнняў, такім чынам канчаткова быў вылучаны пласт «культурнавызначальных рэчаў» для КСПДК (скроневыя колцы 1 тыпа, варыянт а (тыпалогія У. В. Енукова), круглыя арнаментаваныя бляхі з умбонападобным выступам ў цэнтры, трохдзюркавыя ланцугатрымальнікі). Акрэслена праблематыка амаль поўнай адсутнасці храналагічных маркёраў для культуры ${ }^{48}$. У. В. Енукоў у сваім даследаванні абагуліў вядомыя яму матэрыялы 3 усяго арэала кульутры. Высновы, выкладзеныя ў гэтай працы, актуальныя і зараз.

I. А. Гаўрытухін у адным з сваіх артыкулаў закрануў пытанні паходжання і храналогіi маленькіх трапецападобных падвесак 49 Для вырашэння гэтых пытанняў аўтар здзейсніў картаграфаванне максімальна падобных вырабаў з розных тэрыторый. У адну 3 груп аўтар вылучыў маленькія трапецападобныя падвескі, вядомыя па помніках КСПДК. Даследчык высказаў некаторыя высновы наконт усяго масіву падобных знаходак, характэрных для КСПДК: 1) буйныя i моцна арнаментаваныя трапецападобныя падвескі характэрны для позніх комплек- саў; 2) маленькія трапецападобныя падвескі КСПДК можна датаваць у рамках VIIIIX ст.; 3) параўноўваючы трапецападобныя падвескі КСПДК і такія ж прадметы з Падунаўя, а таксама 3 помнікаў пражскай культуры можна сцвярджаць пра шэраг храналагічных, тыпалагічных і функцыянальных адрозненняў; 4) у фарміраванні КСПДК прымалі ўдзел людзі, звязаныя 3 зонай уплыву «среднедунайско-верхнеднепровской дуги культурных контактов VII в.» ${ }^{50}$.

Новыя пытанні ў даследаванні КСПДК былі ўзнятыя В. С. Няфёдавым. Цэлы шэраг артыкулаў дасдедчыка дазваляе па новаму паглядзець на гісторыю ўзнікнення і развіцця КСПДК, пераасэнсаваць храналогію культуры ${ }^{51}$

В. С. Няфёдаў удакладніў тыпалогію скроневых колцаў КСПДК для смаленскай часткі арэала культуры. Ён вылучыў два тыпы скроневых колцаў, і па два варыянты ў кожным з іх. Прынцыпова новым стала вылучэнне даследчыкам у якасці асобнага тыпа 1 пярсцёнкападобных колцаў са спіральным завітком на адным $з$ канцоў (варыянт 1 - завіток вонкі, варыянт 2 - завіток унутр). У тып 2 уваходзяць серпападобныя скроневыя колцы 3 заходзячымі канцамі: варыянт $1-3$ адным сплошчаным канцом, у якім прабіта 4-6 адтулін для мацавання трапецападобных падвесак, варыянт 2 - 3 дзвюма сплошчаны- 
Мал. 4. Эвалюцыя трымальнікаў культуры смаленска-полацкіх доўгіх курганоў, прапанаваная Ю. М. Лесманам

53 Кузьмин, С. Л. (2000). Стратиграфия и некоторые проблемы истории Староладожского поселения VIII-X вв. Stratum Plus, 5, 50-54.

54 Нефёдов, В. С. Височные кольца, 39. мі сіметрычна-заходзячымі канцамі (мал. 3). Па сутнасці, тып два супадае $з$ тыпам 1 паводле тыпалогіi У. В. Енукова. На падставе такой фармальнай прыкметы, як завостраны канец ў колцаў тыпу 1 і 2 варыянт 1 даследчык дапускае думку пра іх выкарыстанне ў якасці завушніц ${ }^{52}$. В. С. Няфёдаў удакладніў храналогію скроневых колцаў: колцы тыпу 1 варыянта 1 датуюцца на падставе прамых аналогій VIII-X стст., тыпу 1 варыянта 2 не пазней за трэцюю чвэрць VIII ст. Скроневыя колцы тыпу 2 варыянта 1 сустракаюцца ў пахаваннях сярэдзіны - другой паловы VIII ст., а таксама ў I будаўнічым ярусе Землянога гарадзішча Старой Ладагі (750-765 г., паводле Кузьміна - Мачынскай ${ }^{53}$, але яны не заўважаны ў комплексах X ст. Серпападобныя скроневыя колцы варыянту 2 бытавалі на працягу ўсяго часу існавання КСПДК, яны сустракаюцца ў пахаваннях сярэдзіны трэццяй чвэрці VIII ст. (Цуркоўка, к. 2, п. 1) i пахваннях другой - трэцяй чвэрці X ст. (Заазер'е, к. 5, п. 4; к. 59, п. 2), а таксама у матэрыялах X ст. на паселішчах Гнёздава i Гарадка на Ловаці.

В. С. Няфёдаў, як і яго папярэднікі, паспрабаваў знайсці прататып серпападобных скроневых колцаў КСПДК. На яго думку, яны паходзяць ад пярсцёнкападобных скроневых колцаў $з$ завітком вонкі. Даследчык выказаў думку, што эвалюцыя скроневых

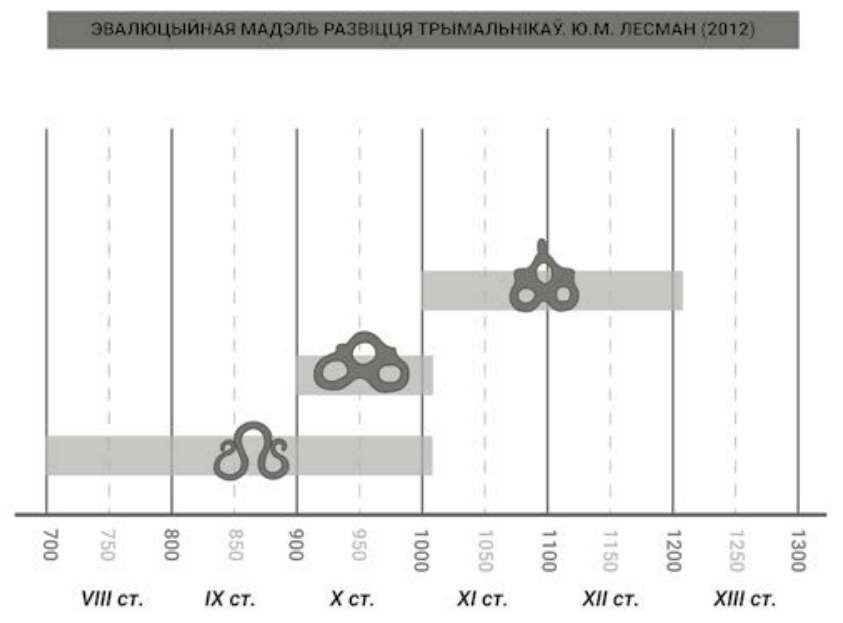

колцаў КСПДК шла па шляху павелічэння іх дыяметра. Такім чынам, выбудавана наступная эвалюцыйная мадэль - пярсцёнкападобныя скроневыя колцы з завітком вонкі (тып 1 варыянт 1) - серпападобныя скроневыя колцы 3 адным сплошчаным канцом, у якім прабіта 4-6 адтулін для мацавання трапецападобных падвесак (тып 2 варыянт 1) (час узнікнення не раней за сярэдзіну VIII ст.) серпападобныя скроневыя колцы 3 дзвума сплошчанымі сіметрычна-заходзячымі канцамі (тып 2 варыянт 2) (мал. 5) ${ }^{54}$.

Закрануў В. С. Няфёдаў і пытанне пра змену серпападобных скроневых колцаў КСПДК бранзалетападобнымі скроневымі колцамі з завязанымі канцамі, якая адбылася ў другой палове X-пачатку XI стст. Ён не лічыць гэтую трансфармацыю дзіўнай, калі 
Мал. 5. Бытаванне скроневых колцаў культуры смаленска-полацкіх доўгіх курганоў на Смаленшчыне, паводле В. С. Няфёдава

55 Там жа, 40.

56 Лесман, Ю. М. Биэсовидные разделители, 228-232.

57 Там жа, 228.

58 Там жа, 229.

59 Там жа, 230-231.

60 Там жа, 231-232.

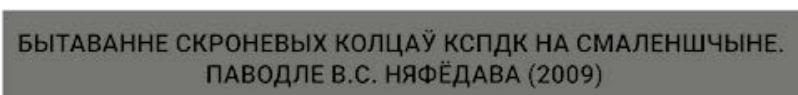

ПАВОДЛЕ В.С. НЯФЁДАВА (2009)

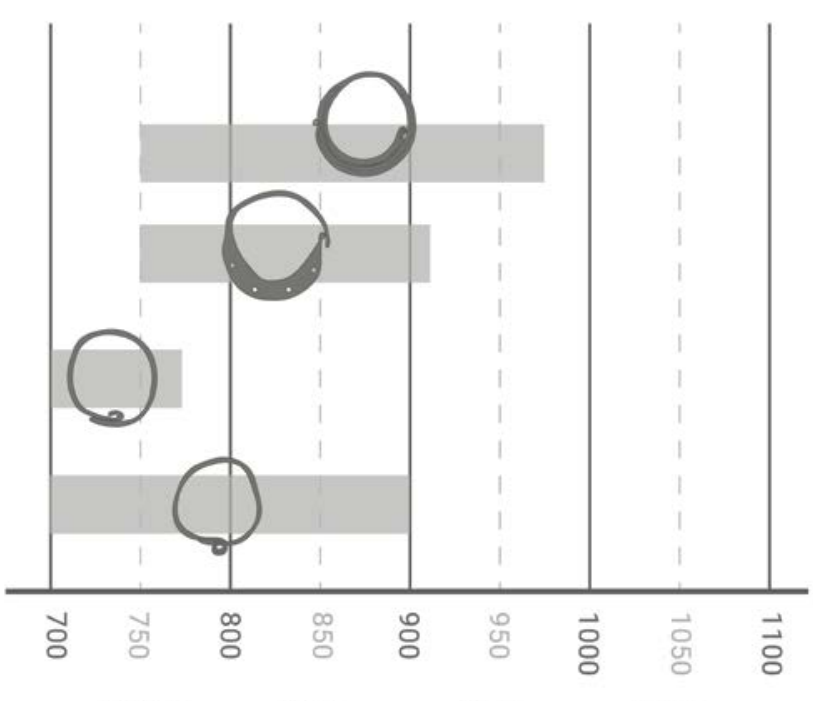

VIII cT.

IX $c T$.

$X C T$.

$X I c T$.

ўявіць, што прататыпам для такіх колцаў выступалі пярсцёнкападобныя скроневыя колцы 3 завязанымі канцамі, якія былі вядомы сярод славянскага насельніцтва Гнёздава ў другой палове X ст. ${ }^{55}$

Сярод прац, прысвечаных «культуравызначальным рэчам» КСПДК, варта ўзгадаць артыкул Ю. М. Лесмана ${ }^{56}$. У ім аўтар прасачыў эвалюцыю такога элемента жаночага ўбору, як бі-S-падобныя трымальнікі на фоне агульных працэсаў развіцця КСПДК у канцы I - пачатку II тыс. н.э. Даследчык датаваў трымальнікі ўсім перыядам існавання культуры - «VIII-X вв., а, на периферии, возможно, и до начала ХІ в.» ${ }^{57}$. Ю. М. Лесман звярнуў увагу на з'яўленне ў КСПДК новага тыпу трымальнікаў - трохдзюркавых літых, якія 3'яўляюцца на заключным этапе развіця культуры. Верхняя мяжа такога тыпу трымальнікаў вызначаецца Ю. М. Лесманам не пазней за пачатак XI ст. (па знаходцы такіх трымальнікаў у курганным могільніку Пагошча, Браслаўскі раён Віцебскай вобласці) ${ }^{58}$. Як наступны крок ў развіцці трымальнікаў КСПДК Ю. М. Лесман бачыць бi-S-падобныя падвескі з дробнай пяцелькай у верхняй частцы (марфалагічныя пераемнікі), якія былі у выкарыстанні на тэрыторыі Старажытнай Русі ў XI-XII ст., магчыма, і ў XIII ст. (мал. 4) ${ }^{59}$.

У артыкуле Ю. М. Лесмана прыводзіцца цікавая выснова наконт трансфармацыі ўпрыгажэнняў КСПДК: пры захаванні формы мяняліся іх функцыі. Асобныя элементы ўбору КСПДК, якія раней ўваходзілі ў нейкія складаныя упрыгажэнні, становяццца аўтаномнымі «... разделители для подвесок, обычно включенных вместе со спиральками в сложное украшение, оказались прототипами автономных подвесок в составе ожерелий. ... ромбовидные подвески, крепившиеся к цепочкам и входившие в состав других сложных металлических украшений, стали основой лепестковых подвесок тоже в составе ожерелий» ${ }^{60}$. 
61 Вайцяховіч, А. В. (2011).

Жаночы пахавальны ўбор X-XII ст. В Лепельскія чытанні: матэрыялы навукова-практычнай канферэниыі (с. 33-41). Мінск: «Медысонт».

62 Вайцяховіч, А. В. (2011). Развіииё форм $i$ відаў пахавальнага абраду на тэрыторыі Полацккай зямлі ў X-XII cmcm. (Дысертацыя на суісканне вучонай ступені кандыдата гістарычных навук: спецыяльнасць 07.00 .06 Археалогія). Мінск.

63 Вайцяховіч, А. В. (2011). Жаночы пахавальны ўбор X-XII ст., 34.

64 Там жа, С. 35.

65 Там жа, С. 36

66 Вайцяховіч, А. В. (2017). Знаходкі металічных арнаментаваных трымальнікаў ланцужкоў на тэрыторыі Віцебскай вобласці. В Віщебскія старажытнасиі: матэрыялы навуковай канферэнцыі, прысвечанай 150-годдзю з дня нараджэння $у$. Г. Краснянскага, Віщебск, 17-18 кастрычніка 2013 г. (с. 36-39). Віцебск.
Адзінай працай, прысвечанай рэканструкцыі жаночага строю насельніцтва Беларускага Падзвіння паводле пахаванняў па абрадзе крэмацыі можна лічыць артыкул А. В. Вяйцяховіча «Жаночы пахавальны ўбор X-XII ст.» ${ }^{61}$. Яшчэ ў сваёй кандыдацкай дысертацыі даследчык паспрабаваў вылучыць пэўныя «традыцыі» развіцця жаночага строю на тэрыторыі Полацкай зямлі на падставе пахавальных помнікаў ${ }^{62}$. Рэканструкцыя была зроблена для наступнага рэгіёна - гэта вытокі р. Бярэзіны Дняпроўскай і сістэма яе правых і левых прытокаў на тэрыторы Докшыцкага і Лепельскага раёнаў Віцебскай вобласці ${ }^{63}$. Даследчыкам вылучаны дзве традыцыі строя, першая атаясамліваецца з КСПДК. Для яе характэрнымі элементамі з'яўляецца галаўны ўбор, які мог складацца 3 асновы і скроневых серпападобных колцаў з заходзячымі канцамі, а таксама «драцяных» скроневых колцаў, прымацаваных да яе. Таксама да ўбору галавы быў аднесены галаўны венчык ${ }^{64}$.

Да ўпрыгажэнняў шыі былі аднесены вітыя грыўні з трох драцін з конусападобнымі ці петлепадобнымі канцамі. Да нагруднага ўпрыгажэння А. В. Вайцяховіч аднёс ўпрыгажэнне, якое складалася 3 ланцужкоў, што замацоўваліся на плячах 3 дапамогай кручкоў (?) ці трохвугольных (трапецападобных) трымальнікаў з трыма адтулінамі. Да ніжніх канцоў ланцужкоў падвешваліся трапецападобныя ці ромбападобныя падвескі. У склад гэтага ўпрыгажэння маглі ўваходзіць буйныя біканічныя пацеркі. Акрамя яго, да нагрудных упрыгажэнняў уваходзілі каралі са шкляных пацерак. Даследчык звярнуў увагу на прысутнасць ў пахаваннях крыжапраразных бразготак, аднак якое месца яны займалі ў сістэме жаночага ўбору, невядома. Да ўпрыгажэнняў рук былі аднесены рознай формы бранзалеты (пукатыя 3 арнаментам «воўчы зуб» і V-падобныя ў сячэнні), а таксама шырокасярэдзінныя пярсцёнкі з «вусатымі канцамі» ${ }^{65}$

Падаецца дзіўным уключэнне ў комплекс жаночых упрыгажэнняў першай традыцыі нагруднага ўпрыгажэння, якое складалася з ланцужкоў, якія замацоўваліся на плячах, бо такая знаходка зафіксавана толькі ў дзвух выпадках ${ }^{66}$, і пакуль што не можа быць сведчаннем распаўсюжання такога ўпрыгажэння на пэўных тэрыторыях, не кажучы ўжо пра існаванне традыцыі.

Некалькі артыкулаў А. В. Вайцяховіча былі прысвечаны абагульненню і аналізу асобных элементаў жаночага ўбору КСПДК. Ён распрацаваў тыпалогію трапецападобных падвесак для беларускай часткі арэала КСПДК і вылучыў тры групы, якія ў сваю чаргу падзяляліся на варыянты. Крытэрыямі для вылучэння выступілі марфалагічныя 
67 Вайцяховіч, А. В. (2014). Знаходкі трапецападобных падвесак у курганах Паўночнай і Цэнтральнай Беларусі. В Беларускае Падзвінне: вопыт, методыка $i$ вынікі палявых $i$ міждысиыплінарных даследаванняў (да 20-годдзя археалагічных $i$ этнаграфічных экспедыцый ПДУ): зб. навук. арт. II Міжнар. навук. канф., Полацк, 17-18 красав. 2014 2. (4. 1, с. 35-40). Наваполацк.

68 Вайцяховіч, А. В. Знаходкі металічных арнаментаваных трымальнікаў ланцужкоў, 38-39. прыкметы. Група II вылучана на падставе адной трапецападобнай падвескі з могільніка Бірулі (Докшыцкі раён Віцебскай вобласці). Варыянты, прыведзеныя ў межах групы I i III вылучаны на падставе традыцый арнаментальнага дэкору. Храналогія бытавання падвесак, аб'яднаных у групу I, на думку аўтара - другая палова VIII - пачатак X стст., група III - першая палова X - пачатак XI ст. Каб уявіць функцыянальнае прызначэнне гэтых рэчаў, А. В. Вайцяховіч прывёў у якасці прыкладу асобныя элементы жаночага строю КСПДК, куды маглі, на яго думку, мацавацца трапецападобныя падвескі ${ }^{67}$

Таксама асобны артыкул А. В. Вайцяховіча прысвечаны рэдкім трапецападобным арнаментаваным трымальнікам з адтулінамі ўнізе (знаходкі з тэрыторыі Віцебскай вобласці), на які маглі мацавацца ланцужкі, ромбападобныя падвескі. Такія трымальнікі былі выяўлены ў пахаваннях па абрадзе крэмацыі ў могільніках Вышадкі і Бірулі (Гарадоцкі, Докшыцкі раёны Віцебскай вобласці). Даследчык адносіць іх да элементаў жаночага строю КСПДК і лічыць часам іх з'яўлення другую палову Х ст. Падобныя трымальнікі, на яго думку, фіксуюцца толькі на беларускай частцы арэала культуры ${ }^{68}$.

\section{Сучасны стан i перспектывы вывучэння жаночага строю КСПДК}

На дадзены момант стан вывучэння жаночага строю можна ахарактарызаваць у некалькіх рэчышчах: палявая праца, камеральная праца і новыя тэарэтычныя напрацоўкі ў галіне вывучэння жаночага строю КСПДК. Зараз накапленне крыніц для вывучэння жаночага строю КСПДК адбываецца дзякуючы палявой працы такіх археолагаў, як М. А. Плавінскі, які займаецца даследаваннямі курганных старажытнасцяў другой паловы I - пачатку II тыс. на паўночным-захадзе Беларусі. Таксама палявымі даследаваннямі могільнікаў, сярод якіх сустракаюцца і пахаванні КСПДК, займаецца А.В. Вайцяховіч, у сферы навуковых цікавасцяу якога знаходзіцца праблематыка трансфармацыі пахавальнага абраду на тэрыторыі Полацкай зямлі. 32018 года даследаваннямі пахавальных старажытнасцяў КСПДК таксама займаецца аўтар дадзенага артыкула. Аднак палявымі даследаваннямі арэал культуры як і раней, так і зараз, ахоплены нераўнамерна.

Побач 3 палявой працай важным для вывучэння жаночага строю КСПДК з'яўляец- 
69 Плавінскі, М. А. (2020). У пошуках новых поглядаў на гісторыю крывічоў Беларускага Падзвіння. Беларускі еістарычны 4aconic, 5, 12-18. ца поўны ўвод у навуковы ўжытак калекцый прадметаў, атрыманых падчас даследаванняў мінулых часоў. Шмат якія калекцыі прадметаў, якія звязаны з насельніцтвам КСПДК, апублікаваны толькі часткова, што не дазваляе асэнсаваць комплексы ў цэлым.

У сувязі з выяўленнем бескурганных пахаванняў КСПДК на тэрыторыі некропаля Наўры II востра ўздымаецца шэраг навуковых пытанняў, адным 3 якіх з'яўляецца суаднясенне бескурганных і курганных пахаванняў КСПДК. На нашу думку, справа будучыні - фіксацыя падобнага тыпу помнікаў ля вядомых курганных могільнікаў КСПДК Таму, даволі перспектыўным з'яўляецца вывучэнне жаночага інвентару 3 такіх могільнікаў.

Нажаль, пакуль застаецца нявырашаным пытанне вылучэння рэчаў хронаіндыкатараў, а таксама пытанне пра час і шляхі пранікнення носьбітаў КСПДК на тэрыторыю Беларускага Падзвіння, хаця некаторыя меркаванні на гэты конт былі выказаны ${ }^{69}$. Але гэта - справа будучых даследаванняў, у якіх галоўная роля адводзіцца асобным элементам жаночага строю.

\section{Высновы}

Такім чынам, ў даследаванні жаночага строю КСПДК можна вылучыць некалькі этапаў. Праз аналіз навковых прац, прысвечаных гэтай тэме, з самага пачатку вывучэння і да сённяшняга часу выяўляецца наступная заканамернасць: асобныя элементы жаночага строю КСПДК абагульняліся даследчыкамі ў групы: ўпрыгажэнні рук, шыі і грудзей, галавы. Але дагэтуль не выпрацаваныя крытэрыі, па якіх асобныя элементы жаночага металічнага ўбору варта ўключаць менавіта ў тую ці іншую групу. Важна асэнсаваць рэч як састаўны элемент больш складанага ўпрыгажэння, і вызначаць функцыянальнае прызначэнне ўпрыгажэння ў цэлым. Для розных пахавальных комплексаў адзін і той жа прадмет можа быць састаўным элементам функцыянальна розных упрыгажэнняў: спіральная пранізка магла быць дэталлю ўпрыгажэння галаўнога венчыка (ўпрыгажэнні галавы), дэталлю караляў (упрыгажэнні шыі і грудзей), і нашыўкай на адзенне. Падобная сітуацыя назіраецца з трапецападобнымі падвескамі, ланцужкамі. Таму важна асэнсаванне рэчаў 
у комплексах, рэканструкцыя строю асобных пахаванняў. Толькі на падставе гэтага можна вылучаць нейкія лакальныя асаблівасці, ці вылучаць традыцыі, характэрыня для носьбітаў КСПДК на ўсім яе арэале.

У пэўнай ступні у даследаваннях жаночага строю КСПДК можна казаць пра панаванне мікрарэгіянальныага падыходу. Праца У.В. Енукова - прыклад даследавання, якое закранае пытанні асобных элементаў жаночага строю КСПДК па ўсім арэале культуры. Астатнія працы, як манаграфічнага характару, так і у форме артыкулаў, сканцэнтрававаны на абагульненне і тыпалагізацыю інвентару па пэўных рэгіёнах: самая поўная тыпалогія скроневых колцаў КСПДК распрацавана В. С. Няфёдавым для смаленскай часткі арэала культуры. Тыпалогіі, прапанаваныя Я. А. Шмідтам з большасці базуюцца на матэрыялах яго ўласных раскопак, якія здзяйсняліся ім на тэрыторыі смаленскай часткі арэала культуры. А. В. Вайцяховічам прапанавана тыпалогія трапецападобных падвесак, якая грунтуецца на матэрыялах 3 беларускай часткі арэала культуры. Добрым прыкладам працы, прысвечанай тыпалогіi, храналогіi, і эвалюцыі трымальнікаў КСПДК з’яўляецца праца Ю. М. Лесмана.

Нягледзячы на тое, што палявыя археалагічныя даследаванні курганных могільнікаў, дзе маюцца старажытнасці КСПДК, у
Смаленскім Падняпрпроўі і Беларускім Падзвінні распачаліся прыкаладна ў адзін і той жа час (сярэдзіна XIX ст.), і працягваюцца зараз, назіраецца разрыў ў ступені тэарэтычных даследаванняў КСПДК паміж беларускімі і расійскімі даследчыкамі. Можна казаць, што на тэрыторыі Беларусі, толькі распачалося мэтанакіраванае вывучэнне матэрыяльнай культуры КСПДК у цэлым, што пакуль не дазваляе казаць пра прысутнасць нейкіх устойлівых набораў і лакальных асаблівасцяў жаночага строю.

\section{Referenses}

Enukov, V. V. (1990). Rannie etapy formirovaniya smolensko-polotskikh krivichei (po arkheologicheskim dannym). Moskva: Znak Pocheta [in Russian].

Enukov, V. V. (2018). Kul'tura smolenskikh dlinnykh kurganov i drevnosti dnepro-donskoi lesostepi. In Arkheologiya Drevnei Rusi: problemy i otkrytiya. Materialy mezhdunarodnoi konferentsii, posvyashchennoi 100-letiyu so dnya rozhdeniya D. A. Avdusina. Trudy istoricheskogo fakul'teta MGU (Vol. 140, pp. 75-77). Moskva: Izdatel'stvo Moskovskogo universiteta [in Russian].

Gavritukhin, I. O. (1997). Malen'kie trapetsievidnye podveski s kaimoi iz pressovannykh tochek po nizhnemu krayu. Gistarychna-arkhealagichny zbornik, 12, 43-58 [in Russian].

Kuz'min, S. L. (2000). Stratigrafiya i nekotorye problemy istorii Staroladozhskogo poseleniya VIII-X vv. Stratum Plus, 5, 50-69. 
Lesman, Yu. M. (2012). Biesovidnye razdeliteli, trekhdyrchatye razdeliteli i biesovidnye podveski: ot kul'tury smolenskikh dlinnykh kurganov k drevnerusskoi kul'ture. In Slavyane Vostochnoi Evropy nakanune obrazovaniya Drevnerusskogo gosudarstva. Materialy mezhdunarodnoi konferentsii, posvyashchennoi 110-letiyu so dnya rozhdeniya Ivana Ivanovicha Lyapushkina (1902-1968) 3-5 dekabrya 2012 g. (pp. 228-232). Sankt-Peterburg [in Russian].

Mikhailova, E. R. (2014). Veshchevoi kompleks kul'tury pskovskikh dlinnykh kurganov: tipologiya i khronologiya. Saarbrücken: LAPLAMBERT Academic Publishing.

Nefedov, V. S. (2000). O vremeni vozniknoveniya kul'tury smolensko-polotskikh dlinnykh kurganov. In Arkheologiya i istoriya Pskova i Pskovskoi zemli: materialy nauch. seminara 1996-1999 (pp. 191-199). Psko [in Russian].

Nefedov, V. S. (2002). Saltovskie drevnosti v smolenskikh dlinnykh kurganakh. Gistarychna-arkhealagichny zbornik, 17, 131-139 [in Russian].

Nefedov, V. S. (2003). Nekotorye zamechaniya ob ukrasheniyakh kul'tury smolenskikh dlinnykh kurganov iz raskopok v Staroi Ladoge. In Ladoga - pervaya stolit sa Rusi. 1250 let nepreryvnoi zhizni. Sed'mye chteniya pamyati Anny Machinskoi (pp. 58-67). Sankt-Peterburg: Nestor-Istoriya, II RAN [in Russian].

Nefedov, V. S. (2009). Visochnye kol'tsa kul'tury smolensko-polotskikh dlinnykh kurganov (po materialam pogrebenii Smolenskogo Podneprov'ya i Podvin'ya). Rossiiskaya arkheologiya, 3, 35-41 [in Russian]

Nefedov, V. S. (2011). Smolenskie krivichi i Rus': severoevropeiskie i drevnerusskie izdeliya $\mathrm{v}$ smolenskikh dlinnykh kurganakh. In Trudy III (XIX) Vserossiiskogo arkheologicheskoyu s'ezda (Vol. II, pp. 75-77). Moskva [in Russian]

Nefedov, V. S. (2012). Rannie etapy politogeneza na na XI v.). In Severnaya Rus'i problemy formirovaniya Drevnerusskogo gosudarstva. Sbornik materialov Mezhdunarodnoi nauchnoi konferentsii (Vologda - Kirillov Belozersk, 6-8 iyunya 2012 g.) (pp. 89-113). Vologda: Drevnosti Severa [in Russian].

Plavinski, M. A. (2011). Polacka-smalenskih dowgih kurganow kul'tura. In Arhealogija Belarusi. jencyklapedyja (Vol. 2, pp. 202-203). Minsk [in Belorusian].

Plavinski, M. A. (2020). U poshukah novyh pogljadaw na gistoryju kryvichow Belaruskaga Padzvinnja. Belaruski gistarychny chasopis, 5, 12-18 [in Belorusian]

Plavinskii, N. A. (2012). K voprosu o finale kul'tury smolensko-polotskikh dlinnykh kurganov v Braslovskom Poozer'e (po materialam raskopok kurgannogo mogil'nika Opsa v 2010 g.). In Slavyane Vostochnoi Evropy nakanune obrazovaniya Drevnerusskogo gosudarstva. Ma terialy mezhdunarodnoi konferentsii, posvyashchennoi 110-letivu so dnya rozhdeniya Ivana Ivanovicha Lyapushkina (1902-1968) 3-5 dekabrya 2012 g. (pp. 225228). Sankt-Peterburg [in Russian].

Pławinski, M., Pławinski, A., Pławinski, U., Tarasiewicz, W., Makouskaja, W., \& Astapowicz, E. (2018). Badania zespołu stanowisk archeologicznych koło ws Nawry, rej. miadzielski obw. miński, w 2017 roku. In Badania archeologiczne w Polsce środkowowschodniej. zachodniej Białorusi $i$ Ukrainie w roku 2017: streszczenia referatów XXXIV konferencji. Lublin, 38.

Sedov, V. V. (1974). Dlinnye kurgany krivichei. Moskva: Nauka [in Russian].

Sedov, V. V. (1982). Vostochnye slavyane v VI-XIII vv. In Arkheologiya SSSR s drevneishikh vremen do srednevekov'ya (Vol. 14). Moskva: Nauka [in Russian].

Sedov, V. V. (1993). Visochnye kol'tsa kul'tury smolensko-polotskikh dlinnykh kurganov. In Chas, pomniki, lyudzi. Pamyatsi represavanykh arkheolagay. Tezisy dakladaỹ mizhnarodnai kanferentsyi $\check{y}$ Minsku 27-30 kastrychnika 1993 g. (pp. 116-118). Minsk [in Russian]. 
Sedov, V. V. (1994). Ocherki po arkheologii slavyan. Moskva [in Russian].

Sedov, V. V. (1995). Slavyane v rannem srednevekov'e. Moskva: NPBO "Fond arkheologii” [in Russian].

Sedov, V. V. (1999). Drevnerusskaya narodnost'. Moskva: Yazyki russkoi kul'tury [in Russian].

Shmidt, E. A. (1968). O smolenskikh dlinnykh kurganakh. In Slavyane i Rus' (pp. 224-229). Moskva: Nauka [in Russian].

Shmidt, E. A. (1970). K voprosu ob etnicheskoi prinadlezhnosti zhenskogo inventarya iz smolenskikh dlinnykh kurganov. In Materialy po issledovaniyu Smolenskoi oblasti (Vol. VII, pp. 219-235). Moskva: Moskovskii rabochii [in Russian].

Shmidt, E. A. (2006). Osobennosti etnokul'turnogo razvitiya plemen Smolenskogo Podneprov'ya i smezhnykh territorii v VIII-X vv. n. e. Gistarychna-arkhealagichny zbornik, 22, 113-120 [in Russian].

Shmidt, E. A. (2008). K voprosu ob etnicheskoi prinadlezhnosti krivichei. In Romanovskie chteniya - 4: sbornik trudov Mezhdunarodnoi nauchnoi konferentsii, 22-23 noyabrya 2007 goda, g. Mogilev (pp. 100-102) Mogilev [in Russian].

Shmidt, E. A. (2012). Krivichi Smolenskogo Podneprov'ya i Podvin'ya (v svete arkheologicheskikh dan$n y k h)$. Smolensk [in Russian].

Shmidt, E. A. (2013). Shugailovo (kompleks arkheologicheskikh pamyatnikov). Smolensk: Svitok [in Russian].

Shtyhaw, G. V. (1992). Kryvichy: pa matjeryjalah raskopak kurganow u Pawnochnaj Belarusi. Minsk: Navuka i tjehnika [in Belorusian].

Spitsyn, A. A. (1899). Rasselenie drevnerusskikh plemen po arkheologicheskim dannym. Zhurnal Ministerstva narodnogo prosveshcheniya, 301-340 [in Russian].
Spitsyn, A. A. (1903). Udlinennye i dlinnye kurgany. In Zapiski otdeleniya russkoi i slavyanskoi arkheologii Russkogo arkheologicheskogo obshchestva (V (1), pp. 196-202). Sankt-Peterburg: Tip. I. N. Skorokhodova [in Russian].

Vajcjahovich, A. V. (2011). Razviccjo form i vidaw pahaval'naga abradu na tjerytoryi Polackaj zjamli w $X$-XII stst. (Dysertacyja na suiskanne vuchonaj stupen kandydata gistarychnyh navuk: specyjal'nasc' 07.00 .06 Arhealogija). Minsk [in Belorusian].

Vajcjahovich, A. V. (2011). Zhanochy pahaval'ny wbor X-XII st. In Lepel'skija chytanni: matjeryjaly navukova-praktychnaj kanferjencyi (pp. 33-41). Minsk: "Medysont" [in Belorusian].

Vajcjahovich, A. V. (2014). Znahodki trapecapadobnyh padvesak u kurganah Pawnochnaj i Cjentral'naj Belarusi. In Belaruskae Padzvinne: vopyt, metodyka i vyniki paljavyh i mizhdyscyplinarnyh dasledavannjaw (da 20 goddzja arhealagichnyh $i$ jetnagrafichnyh jekspedycyj PDU): zb. navuk. art. II Mizhnar. navuk. kanf., Polack, 17-18 krasav. 2014 g. (Vol. 1, pp. 35-40) Navapolack [in Belorusian].

Vajcjahovich, A. V. (2017). Znahodki metalichnyh arnamentavanyh trymal'nikaw lancuzhkow na tjerytoryi Vicebskaj voblasci. In Vicebskija starazhytnasci: matjeryjaly navukovaj kanferjencyi, prysvechanaj 150-goddzju z dnja naradzhjennja U.G. Krasnjanskaga, Vicebsk, 17-18 kastrychnika 2013 g. (pp. 36-39). Vicebsk [in Belorusian].

Volkaite-Kulikauskene, R. (1997). Odezhda $i$ ukrasheniya baltov (I-XVI vv.). Vilnius, Lietuvos Istorijos instituto [in Russian].

Zarinya, A. (1960). Latgal'skie zhenskie golovnye venki vainagi - VI-XIII vv. In Arheologia un etnografia. Rakstu krejums (Vol. 2, pp. 79-95). Riga [in Russian].

Zarinya, A. (1970). Odezhda drevnikh latgalov. VIIXIII vv. Riga: Zinatne [in Russian]. 


\section{THE HISTORY OF STUDYING WOMEN'S JEWELRY ATTIRE OF SMOLENSK-POLOTSK LONG BARROWS CULTURE: RESULTS AND THE CURRENT STATE}

The article is devoted to the history of studying, as well as to the analysis of how deeply women's metal attire (suit) of Smolensk-Polotsk long barrows culture is studied, which is usually identified with the Krivichs from annalistic chronicles. The author analyzed a number of scientific publications, on the basis of which it was concluded that a focused study of this issue had begun in the 1960s. In the studies of women's jewellery attire of the Krivichs three periods can be distinguished. The initial period (1960s - early 1990s) is characterized by a gradual departure from the perception of women's attire of "the culture of long barrows" only as a source of research. Attire became the subject of research. The second period (1990s - 2017) is characterized by studying of women's attire in terms of the Culture of Smolensk-Polotsk Long Barrows (SPLBK) on purpose. At that time, fairly detailed typologies of particular elements of the SPLBK women's attire appeared. Since 2017 the third period has begun (2017 - present). It is determined based on discovery of moundless burials of the KSPDK in which new "atypical" women's jewellery is found. It makes researchers rethink the tradition of a funeral rite and specific elements of the Krivichi women's attire E.A. Schmidt, V.V. Sedov, V.V. Enukov, V.S. Nefyodov are among the main researchers. As a result of multiple years research, things that act as "cultural markers" were identified. Typologies and a chronology of individual elements of women's metal attire were suggested: temple rings, head ornaments, holders. It has been established that in the study of women's jewelry attire SPLBK the "micro-regional approach" prevails: typologies of inventory are predominantly based on materials from Smolensk part of the cultural area. Thus, there is a 'gap' between Russian and Belarusian researchers in how deeply women's metal attire is studied. In Belarus, the study of its local characteristics and chronology has just begun.

Keywords: Smolensk-Polotsk long barrows culture, Belarusian Dvina region, women's jewelry attire, E.A. Schmidt, V.V. Sedov, V.V. Enukov, V.S. Nefyodov. 